strated, $2 \frac{1}{2}$ years later. The team which saw the Freddy project through consisted of A.P. Ambler, H.G. Barrow, C.M. Brown, R.M. Burstall and R.J. Popplestone (see their paper in Artificial Intelligence Summer 1975); and on the hardware side S. Salter (mechanical engineering) and Gregan Crawford (electronics).

It should also be recalled that the founding giants of $\mathrm{AI}$, men such as Samuel, Simon, Newell, McCarthy, Minsky, Robinson and Rosen had been labouring to set the cornerstones some ten years before Gregory was captured by his dream of flower and fruit. But the bold literary approximation sometimes economically conveys a deeper truth. Before he left Edinburgh Gregory taught us that if a robot is to see, then its programmers must enable it to reconstruct its percepts, as does the human being, from a stored inventory of how the components of familiar objects and scenes normally look. This Helmholtzian doctrine is a cliché of computer vision today. In those days it was not, and the launching orientation was derived, to speak for myself, in powerful measure from Gregory.

From time to time in the book this gift flashes forth to astonish, illuminate and (occasionally) to infuriate. It is human to be irked by an inspired guide who against overwhelming odds brings one to the right door, only to signal by tell-tale fumblings that he lacks the door key. But is it rational to be irked? Who else could have piloted one thus far? Moreover one is perfectly free to thank him and look for a key-owner or a locksmith. Gregory has seen from afar that the instruments of thought-automation are the "tools", "materials" and "processes" of a new industry, the technology of human knowledge. On approaching closer, his expertise gives out, just where that of the new race of knowledge engineers begins. The important thing, however, is that his insight is correct.

The book's pivotal chapter, "The Nature and Nurture of Intelligence", will stir profitable thought in laboratories where man-machine synthesis of prototype knowledge systems is making precise what Gregory's mind's eye has spied. As with the book as a whole, the chapter tells everything about the philosophy of AI, nothing of the method.

It also tells on every page a very great deal about its author. From this comes many flaws, but much charm. One of the joys of the scientific life is to drop for a while the customary pendantries in exchange for good companionship. Mind in Science offers sustenance of just this kind. Possibly some scientific or philosophical people may abstain from its pages. They must be warned that they will have to continue their journey more poorly supplied than need have been the case.

\title{
Cell transformation: a missed opportunity
}

\section{Daniel Rifkin}

Neoplastic and Normal Cells in Culture. Developmental and Cell Biology, 8. By J.M. Vasiliev and I.M. Gelfand. Pp.372. ISBN 0-521-23149-3. (Cambridge University Press: 1981.) £40, \$79.50.

THE enormous increase of interest over the past ten years in the molecular biology of tumour viruses, as well as in the physiology of cultured cells, has created an extensive literature on the properties of normal and transformed cells, and on the relationships of these properties to the cellular phenotype. There is no book currently available which brings together the large body of information accumulated in this area. Thus, it was with pleasure that I began Vasiliev and Gelfand's book Neoplastic and Normal Cells in Culture. The aim of the authors is "to describe and discuss comparative characteristics of the interactions of normal and neoplastic cells with their environment in cell cultures". The book, then, would appear to be the perfect vehicle for a synthesis of data on those properties of neoplastic cells responsible for their altered growth, their invasive behaviour and their metastatic potential, specifically as measured by in vitro criteria.

The book is divided into four parts. Part 1 , an introduction, is subdivided into two sections: the first covers the general properties of neoplastic cells, especially growth, and the second deals with neoplastic transformation in culture by a variety of agents. The second part of the book, "Morphogenesis in "Normal and Transformed Cultures',' is concerned with cellular structures and their function in relation to morphogenesis. This includes the movement of normal fibroblasts and epithelial cells in relation to their morphology, the locomotion and morphology of tumour cells, and specific biochemical or cytological processes whose alteration may be responsible for the difference between normal and transformed cells. Part 3 deals with growth regulation in normal and transformed cells, concentrating on the anchorage, density and soluble factor controls of cell division, and the interactions of these phenomena. The book concludes with a general discussion based on a comparison of in vitro and in vivo malignant cells as well as the interrelationships of transformation properties.

Within the scope of the authors' aims, the book is filled with interesting references and intriguing observations. The authors present a number of thoughtful conclusions and certainly point out certain ambiguities in the data from different laboratories.

However, the book has two serious deficiencies. The first of these is the cursory discussion of the possible significance of cell-matrix interactions in determining the cellular phenotype. The possible influences of fibronectin, collagen and proteoglycans on cell behaviour are given little more than two paragraphs. This is a rather exciting area of current experimentation but it is presented essentially as an adjunct to the more morphological research. This, in fact, is the second shortcoming of the book - the emphasis on morphological aspects to the virtual exclusion of biochemical analysis. An enormous variety of cellular phenomena is described, but only in a few instances is there any discussion of the possible molecular basis for these phenomena.

But perhaps the most disappointing aspect of the book is its blandness. All of the information presented receives much the same degree of emphasis and enthusiasm. The authors rarely indicate a preference for one interpretation versus another, nor do they ever criticize omissions in the data, the lack of proper controls or internal inconsistencies. This is not a critical presentation of the data. It was rather disheartening to read through a book concerned with an area of such excitement and find only a compendium of facts. The failure to create any larger order out of the enormous amount of information available must be counted as a missed opportunity.

Daniel Rifkin is an Associate Professor of Cell Biology at New York University Medical School.

\section{Resources on a plate}

\section{Frederick J. Sawkins}

Economic Geology and Geotectonics. Edited by D.H. Tarling. Pp.213. ISBN UK 0-632-00738-9/ISBN US 0-470-27145-0. (Blackwell Scientific/Halsted Press: 1981.) $£ 15, \$ 54.95$.

THE possible relationships of resources of various kinds to geotectonics is a subject that is attracting considerable attention nowadays, and this volume was apparently conceived with the object of providing an introduction to anyone - undergraduates, postgraduates and even seasoned researchers - with an interest in the field. Sadly, the book failed to live up to my initial expectations. It contains nine chapters by eight contributing authors, and opens with an introduction to the general theory and operation of plate tectonics. Although somewhat sparsely illustrated, this account provides a competent 